\title{
Formulasi dan Uji Efektivitas Sediaan Body scrub Labu Kuning (Cucurbita moschata)
}

\section{Leny $^{*, 1}$, Indra Ginting ${ }^{1}$, Tiary N Sitohang ${ }^{1}$, Siti Fatimah Hanum ${ }^{1}$, Ihsanul Hafiz ${ }^{1}$, Benni Iskandar ${ }^{2}$}

${ }^{1}$ Fakultas Farmasi dan IImu Kesehatan, Institut Kesehatan Helvetia, Medan, Sumatera Utara, Indonesia

${ }^{2}$ Departemen Farmasetika, Fakultas Farmasi, Sekolah Tinggi IImu Farmasi Riau, Pekanbaru, Riau, Indonesia

*Email: leny@helvetia.ac.id

(Submit 27/7/2021, Revisi 10/8/2021, Diterima 19/8/2021, Terbit 23/8/2021)

\begin{abstract}
Abstrak
Penggunaan body scrub merupakan salah satu perawatan kulit untuk mengangkat sel-sel kulit mati akibat radikal bebas, labu kuning merupakan salah satu tanaman yang banyak mengandung beta karoten serta vitamin $C$ dan $E$ yang berfungsi sebagai antioksidan alami untuk menangkal radikal bebas pada kulit. Penelitian ini bertujuan untuk membuat formulasi sediaan krim body scrub yang mengandung sari labu kuning (Cucurbita moschata). Sari labu kuning diformulasikan dalam variasi konsentrasi $10 \%$, $15 \%$ dan $20 \%$. Evaluasi formula krim body scrub yang dilakukan meliputi uji homogenitas, organoleptis, $\mathrm{pH}$, stabilitas menggunakan metode cycling test, uji iritasi pada kulit, dan efektivitas pada kulit dengan mengamati kemampuan menghaluskan kulit dan meningkatkan kadar air pada kulit dengan menggunakan perangkat skin analyzer. Hasil penelitian menunjukkan bahwa sediaan krim body scrub sari labu kuning (Cucurbita moschata) homogen saat difomulasikan, memiliki bentuk, warna, tidak berubah setelah pengujian stabilitas dengan metode cycling test, dan mempunyai nilai $\mathrm{pH}$ yang memenuhi persyaratan $\mathrm{pH}$ kulit, serta tidak menimbulkan iritasi pada kulit sukarelawan. Sediaan yang dengan konsentrasi sari labu kuning $20 \%$ (F3) memiliki efektivitas paling mendekati kontrol positif yaitu mampu memperbaiki kehalusan kulit (evenness) hingga 50,00\% dan meningkatkan kadar air (moisture) hingga 46,33\%. Kesimpulan dari penelitian ini adalah sari labu kuning (Cucurbita moschata) dapat diformulasikan dalam bentuk sediaan krim body scrub yang stabil dan mampu memperbaiki kondisi kulit yang kasar menjadi lebih baik.
\end{abstract}

Kata kunci: body scrub, Cucurbita moschata, efektivitas, sari labu kuning

\section{Pendahuluan}

Labu kuning merupakan tanaman yang telah lama dikenal dan banyak digunakan dalam olahan pangan, namun belum banyak digunakan sebagai bahan baku industri kosmetik padahal labu kuning memiliki kandungan antioksidan yang memiliki banyak manfaat terhadap kulit yaitu komponen pada kandungan vitamin $C$, vitamin $E$, dan $\beta$-karotennya ${ }^{1}$. Akhir-akhir ini banyak dikembangkan penelitian yang berfokus pada bahan alam dalam pembuatan kosmetik. Manfaat bahan alam yang dapat diambil antara lain sifat antioksidannya dapat menghambat radikal bebas sehingga dapat dikembangkan untuk mencegah proses penuaan dini $^{2}$. 
Menurut penelitian Dokrigumulung (2017) tanaman labu memiliki kandungan beta karoten pada ekstraksi dengan potreleum eter (EPE) diperoleh kadar beta karoten yaitu $39,1 \mu \mathrm{g} / \mathrm{g}$ dan ekstrak etanol (EET) menghasilkan beta karoten sebesar $7,9 \mu \mathrm{g} / \mathrm{g}^{3}$. Berdasarkan Beauty Jurnal oleh Andini Aprilliana (2017), buah labu kuning bermanfaat untuk merawat kecantikan kulit. Labu kuning memiliki kandungan khusus sebagai antiinflamasi yang baik dalam mengatasi masalah jerawat ${ }^{4}$.

Labu kuning juga bermanfaat untuk melawan tanda-tanda penuaan di kulit akibat serangan radikal bebas. Selain mampu menangkal radikal bebas, labu kuning juga mengandung enzim fungsinya mirip dengan kandungan alpha-hydroxy yang kerap dijumpai pada produk-produk pencerah kulit. Kandungan vitamin $\mathrm{E}$ dan antioksidan lain yang terkandung dalam labu kuning sangat baik untuk perawatan kulit ${ }^{5-6}$.

Pada penelitian sebelumnya yang dilakukan oleh Safitri (2011) yang memformulasikan sediaan krim pelembab yang mengandung buah labu kuning (Cucurbita moschata). Ekstrak yang digunakan yaitu ekstrak kering dengan metode pengeringan freeze drying. Pada penelitian tersebut dibuat empat formula. Konsentrasi labu kuning yang digunakan yaitu $2,5 \%, 5 \%, 7,5 \%$, dan $10 \%$. Hasil uji pada penelitian ini menunjukkan sediaan mampu mengurangi penguapan air pada kulit?

Kandungan gula sebagai bahan aktif banyak terdapat pada airnya, buah labu kuning sendiri terdiri dari $90 \%$ air, sehingga tidak diperlukan pelarut lagi untuk memperoleh sarinya ${ }^{8}$. Banyaknya sukrosa dalam labu kuning menjadikannya mampu melembabkan kulit dengan menarik air di udara sehingga ikatan antara air dan sukrosa menyebabkan proses kristalisasi dan mampu membuat air bertahan di dalamnya ${ }^{9}$. Body scrub atau lulur mandi merupakan sediaan yang dipakai ketika kulit dalam keadaan basah mampu mengangkat kotoran dan sel kulit mati sehingga mampu menghaluskan kulit tubuh dan membuat kulit tampak lebih cerah ${ }^{10}$.

Scrub merupakan salah satu treatment pertama yang diberikan sebelum dilanjutkan pada treatment berikutnya pada pelayanan perawatan kulit dan kecantikan, dengan adanya pengembangan formulasi body scrub dengan pemanfaatan labu kuning sebagai bahan aktifnya, serta melakukan uji efektivitas sediaan terhadap kulit manusia, diharapkan dapat meningkatkan nilai guna labu kuning ke dalam perkembangan kosmetik di Indonesia. Efektivitas sediaan dapat dibuktikan dengan perbaikan kehalusan (evenness) dan peningkatan kadar air (moisture) pada kulit ${ }^{11}$.

\section{Metode}

\section{Alat}

Alat-alat yang digunakan dalam penelitian ini adalah waterbath (B-One, China), juicer (Krisbow, Indonesia), skin analyzer (Aramo, Korea), moisture checker (Aramo, Korea), $\mathrm{pH}$ meter (Hanna Instrument, Singapore), batang pengaduk, cawan porselin (Haldenwanger, Berlin), alat gelas (Pyrex, USA), lumpang dan alu (Rofa, Indonesia), 
pipet tetes (Pyrex, USA), spatula (Haiju, China), dan timbangan digital (Fujitsu, Jepang).

\section{Bahan}

Bahan-bahan yang digunakan dalam penelitian ini adalah sari buah labu kuning, asam stearat industry grade 99,7\% (Bratachem), aquadest murni (CV Rudang Jaya), trietanolamin industry grade 97\% (Bratachem), propilen glikol medicine grade 99,5\% (Bratachem), metil paraben food grade 98\% (Bratachem), setil alkohol cosmetic grade (Bratachem), eksfolian cosmetic grade (PT Stara Bintang Surya) dan parfum vanilla cosmetic grade 99\% (CV Rudang Jaya).

\section{Prosedur Rinci}

\section{Pembuatan Sari Buah Labu Kuning (Cucurbita moschata)}

Sebanyak $10 \mathrm{~kg}$ labu kuning yang telah disortasi dicuci, dikupas dan dipotong dalam bentuk dadu, kemudian dijuicer sampai didapatkan sari kemudian dipekatkan di atas waterbath dengan suhu terjaga $40-60^{\circ} \mathrm{C}$.

\section{Prosedur pembuatan body scrub sari labu kuning (Cucurbita moschata)}

Dilebur fase minyak yang terdiri dari setil alkohol dan asam stearat di atas penangas air pada suhu $70^{\circ} \mathrm{C}$. Dilarutkan fase air yang terdiri dari propilen glikol, trietanolamin, metil paraben dengan aquadest panas. Dicampurkan kedua fase hingga didapatkan massa krim yang lembut. Kemudian sari buah labu kuning dimasukkan ke dalam campuran tersebut digerus sampai homogen, setelah itu ditambahkan eksfolian, dihomogenkan dengan menggunakan sudip kemudian ditambahkan parfum ${ }^{12}$. Formulasi sediaan dapat dilihat pada rancangan tabel 1.

Tabel 1 Formulasi sediaan body scrub sari labu kuning (Cucurbita moschata)

\begin{tabular}{lcccc}
\hline \multirow{2}{*}{\multicolumn{1}{c}{ Bahan }} & \multicolumn{5}{c}{ Formula body scrub } \\
\cline { 2 - 5 } & F0 & F1 & F2 & F3 \\
\hline Sari buah labu kuning $(\mathrm{g})$ & - & 10 & 15 & 20 \\
Setil alkohol $(\mathrm{g})$ & 1 & 1 & 1 & 1 \\
Trietanolamin & 2 & 2 & 2 & 2 \\
Propilen glikol $(\mathrm{g})$ & 5 & 5 & 5 & 5 \\
Metil paraben $(\mathrm{g})$ & 0,3 & 0,3 & 0,3 & 0,3 \\
Asam stearat $(\mathrm{g})$ & 15 & 15 & 15 & 15 \\
Parfum vanilla & 3 tetes & 3 tetes & 3 tetes & 3 tetes \\
Eksfolian $(\mathrm{g})$ & 5 & 5 & 5 & 5 \\
Aquadest ad $(\mathrm{ml})$ & 50 & 50 & 50 & 50 \\
\hline
\end{tabular}




\section{Evaluasi Mutu Sediaan Body scrub}

Evaluasi meliputi pemeriksaan homogenitas, uji stabilitas fisik dengan metode stabilitas dipercepat, penentuan nilai $\mathrm{pH}$, uji iritasi kulit dan uji efektivitas sediaan body scrub terhadap sukarelawan ${ }^{13}$.

\section{Uji homogenitas}

Pemeriksaan dilakukan dengan mengoleskan 0,5gram sediaan pada objek glass kemudian ditutup dengan kaca lainnya, diratakan dan diamati ketercampuran dari sediaan yang dibuat, tidak terlihat adanya warna yang tidak merata dan partikel asing ${ }^{13}$.

\section{Stabilitas frezee-thaw/ cycling test}

Sediaan body scrub disimpan pada suhu $4^{\circ} \mathrm{C}$ selama 24 jam, lalu sediaan dipindahkan pada suhu $40^{\circ} \mathrm{C}$ selama 24 jam (1 siklus). Pengujian ini dilakukan sebanyak 6 siklus (selama 12 hari), setiap pergantian siklus dilakukan pengamatan terhadap sediaan body scrub ${ }^{14}$.

\section{Penentuan nilai $\mathrm{pH}$}

Pengujian $\mathrm{pH}$ menggunakan $\mathrm{pH}$ meter yang terlebih dahulu dikalibrasi dengan menggunakan larutan buffer standar netral $(7,01)$ dan larutan buffer $\mathrm{pH}$ asam $(4,01)$ hingga alat menunjukkan harga $\mathrm{pH}$ tersebut. Kemudian elektroda dicuci dengan aquadest, lalu dikeringkan dengan tisu, sampel dibuat dengan masing-masing konsentrasi yaitu ditimbang $1 \mathrm{~g}$ sediaan dan dilarutkan hingga $100 \mathrm{ml}$ air suling. Kemudian elektroda dicelupkan dalam larutan tersebut dan dibiarkan alat menunjukkan harga $\mathrm{pH}$ sampai konstan. Angka yang ditunjukkan $\mathrm{pH}$ meter merupakan $\mathrm{pH}$ sediaan. Pengujian dilakukan sebanyak tiga kali pengulangan untuk setiap pengukuran $\mathrm{pH}$ sediaan ${ }^{15}$.

\section{Uji Iritasi terhadap kulit sukarelawan}

Sediaan yang diujikan pada 12 orang sukarelawan wanita usia 18-25 tahun, dengan cara mengolekan sediaan body scrub sari buah labu kuning di belakang telinga selama 24 jam. Setelah 24 jam sejak pengolesan pertama, kemudiaan dilihat dan diamati reaksi yang terjadi. Reaksi positif ditandai oleh adanya kemerahan, gatal-gatal, atau bengkak pada kulit yang diberi perlakuan ${ }^{16}$.

\section{Uji efektivitas sediaan krim body scrub sari labu kuning}

Pengujian efektivitas dilakukan terhadap sukarelawan sebanyak 15 orang dan dibagi menjadi 5 kelompok yaitu kelompok blanko (F0), kelompok body scrub 10\% (F1), kelompok body scrub 15\% (F2), kelompok body scrub 20\% (F3), dan kelompok kontrol positif. 
Semua sukarelawan diukur kondisi awal kulit pada siku tangan dengan menggunakan skin analyzer yang meliputi kehalusan (evenness) dan moisture checker untuk mengukur kadar air (moisture). Perawatan mulai dilakukan dengan mengaplikasikan krim body scrub hingga merata pada area siku tangan yang telah ditandai sebanyak dua kali seminggu, body scrub diaplikasikan berdasarkan kelompok yang telah dibagi sebelumnya. Kondisi kulit diamati dan diukur setiap minggunya selama 4 minggu pengamatan dengan menggunakan skin analyzer dan moisture checker. Pengujian dilakukan sebanyak tiga kali untuk setiap pengukuran kemudian dirata-ratakan. Perubahan kondisi kulit dihitung saat sebelum dan setelah aplikasi body scrub kemudian distatistikkan. Kehalusan kulit (evenness) yang baik ditunjukkan dengan adanya penurunan angka pada skin analyzer sedangkan pada kadar air (moisture) diharapkan terjadi peningkatan angka kadar air pada kulit setelah menggunakan body scrub labu kuning ${ }^{11}$.

\section{Analisis Data}

Data hasil penelitian dianalisis menggunakan program SPSS. Data dianalisis dengan menggunakan metode One Way Anova untuk menentukan perbedaan rata-rata diantara kelompok.

\section{Hasil}

\section{Hasil Pembuatan Body Scrub (Cucurbita moschata)}

Sediaan yang diperoleh berupa body scrub berbentuk krim, untuk F0 atau blanko, sediaan berwarna putih, untuk F1 hingga F3 sediaan berwarna kuning muda hingga kuning tua. Semua sediaan mempunyai bau khas aroma labu dan vanilla sebagai odoris yang ditambahkan pada sediaan. Semua sediaan body scrub homogen, mempunyai warna yang merata dan tidak terdapat gumpalan. Dengan demikian sediaan dapat dikatakan memenuhi persyaratan homogenitas ${ }^{13}$. Sediaan body scrub dapat dilihat pada gambar 1 .

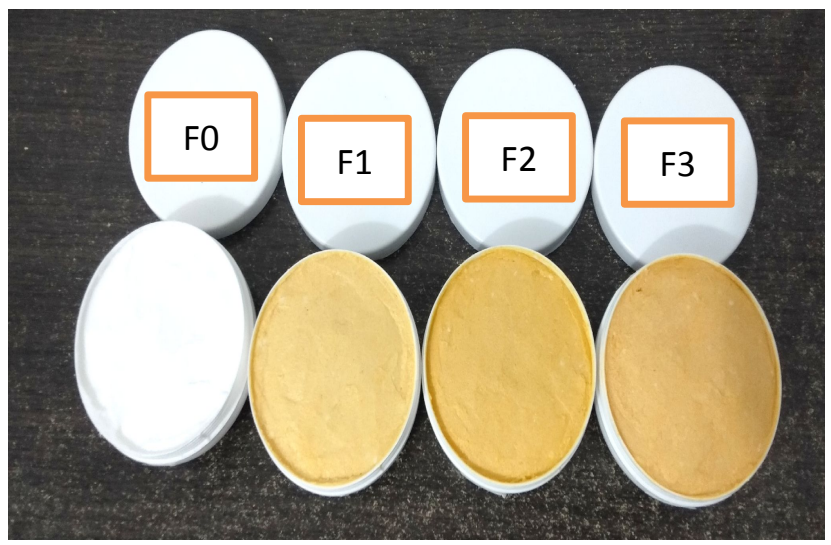

Ket: F0= Sediaan body scrub tanpa labu kuning; F1= Sediaan body scrub labu kuning 10\%; F2= Sediaan body scrub labu kuning 15\%; F3= Sediaan body scrub labu kuning 20\% 
Hasil pengamatan stabilitas sediaan krim body scrub

Evaluasi kestabilan dilakukan dengan menggunakan metode cycling test. Dalam evaluasi krim body scrub ada beberapa parameter yang dilihat yaitu suatu perubahan dalam penampilan fisik, warna, bau, bentuk, dan $\mathrm{pH}$. Dimana pada saat sebelum dan sesudah pengujian, sediaan tidak menunjukkan adanya perubahan pada bentuk, warna serta bau, sehinggan sediaan dapat dinyatakan stabil selama penyimpanan ${ }^{14}$. Hasil stabilitas sebelum dan sesudah cycling test dapat dilihat pada tabel 2.

Tabel 2 Hasil pengamatan stabilitas dipercepat

\begin{tabular}{lcccccccc}
\hline \multirow{2}{*}{ Pengamatan } & \multicolumn{3}{c}{ Sebelum cycling test } & \multicolumn{3}{c}{ Sesudah cycling test } \\
\cline { 2 - 8 } & Basis & F1 & F2 & F3 & Basis & F1 & F2 & F3 \\
\hline Bentuk & Krim & Krim & Krim & Krim & Krim & Krim & Krim & Krim \\
Warna & Putih & Kuning & Kuning & Kuning & Kuning & Kuning & Kuning & Kuning \\
& & tua & muda & muda & Tua \\
Bau & Aroma & Aroma & Aroma & Aroma & Aroma & Aroma & Aroma & Aroma \\
& vanilla & vanilla & vanilla & vanilla & vanilla & vanilla & vanilla & vanilla \\
\hline
\end{tabular}

Keterangan:

F0 : sediaan krim body scrub tanpa sari labu kuning (blanko)

F1 : sediaan krim body scrub sari labu kuning $10 \%$

F2 : sediaan krim body scrub sari labu kuning $15 \%$

F3 : sediaan krim body scrub sari labu kuning $20 \%$

\section{Hasil pengukuran $\mathrm{pH}$ sediaan body scrub}

Pengukuran $\mathrm{pH}$ sediaan dilakukan pada saat sebelum dilakukan penyimpanan dan selama penyimpanan dilakukan pengujian pada setiap siklus cycling test. Hasil menunjukkan sedikit penurunan pada angka $\mathrm{pH}$ yang dapat disebabkan oleh peruraian zat aktif dalam sari labu kuning. Namun perubahan $\mathrm{pH}$ masih tetap dalam range $\mathrm{pH}$ sediaan untuk kulit ${ }^{11}$. Pengukuran $\mathrm{pH}$ sediaan krim body scrub dilakukan dengan menggunakan alat $\mathrm{pH}$ meter dapat dilihat pada tabel 3 .

Tabel 3 Hasil rata-rata nilai $\mathrm{pH}$ sebelum dan sesudah cycling test.

\begin{tabular}{|c|c|c|c|c|c|c|c|c|}
\hline \multirow[b]{2}{*}{ No } & \multirow[b]{2}{*}{ Formula } & \multirow{2}{*}{$\begin{array}{l}\text { Sebelum } \\
\text { cycling } \\
\text { test }\end{array}$} & \multicolumn{6}{|c|}{ pH sesudah cycling test } \\
\hline & & & Siklus 1 & Siklus 2 & Siklus 3 & Siklus 4 & Siklus 5 & Siklus 6 \\
\hline 1 & F0 & 6,1 & 5,9 & 5,8 & 5,5 & 5,4 & 5,2 & 5,0 \\
\hline 2 & F1 & 6,2 & 5,8 & 5,6 & 5,4 & 5,1 & 5,0 & 4,7 \\
\hline 3 & $\mathrm{~F} 2$ & 6,2 & 6,0 & 5,4 & 5,2 & 5,0 & 5,0 & 4,9 \\
\hline 4 & $\mathrm{~F} 3$ & 6,1 & 6,0 & 5,5 & 5,4 & 5,4 & 5,3 & 5,2 \\
\hline $\begin{array}{l}\text { Feterc } \\
\text { F0 } \\
\text { F1 } \\
\text { F2 } \\
\text { F3 }\end{array}$ & $\begin{array}{l}\text { : sediaan } \mathrm{k} \\
\text { : sediaan } \mathrm{k} \\
\text { : sediaan } \mathrm{k} \\
\text { : sediaan } \mathrm{k}\end{array}$ & $\begin{array}{l}\text { im body scruk } \\
\text { im body scruk } \\
\text { im body scruk }\end{array}$ & sari labu k & $\begin{array}{l}\text { labu kuning } \\
\text { uning } 10 \% \\
\text { uning } 15 \% \\
\text { uning } 20 \%\end{array}$ & (blanko) & & & \\
\hline
\end{tabular}




\section{Hasil Uji Iritasi Terhadap Sukarelawan}

Berdasarkan dari hasil uji iritasi yang dilakukan pada 12 sukarelawan yaitu dilakukan dengan cara mengoleskan sediaan krim body scrub dibagian belakang telinga yang telah melalui pengujian stabilitas cycling test dan hasilnya menunjukkan bahwa semua sukarelawan memberikan hasil negatif terhadap parameter reaksi iritasi. Parameter yang diamati yaitu adanya kulit merah, dan pembengkakan setelah sediaan diaplikasikan. Dari hasil uji iritasi yang dilakukan, disimpulkan bahwa sediaan yang dibuat aman untuk digunakan ${ }^{17}$.

Hasil Pengujian Efektivitas Sediaan Krim Body Scrub yang meliputi pengukuran kehalusan kulit sukarelawan dapat dilihat pada Gambar 1.

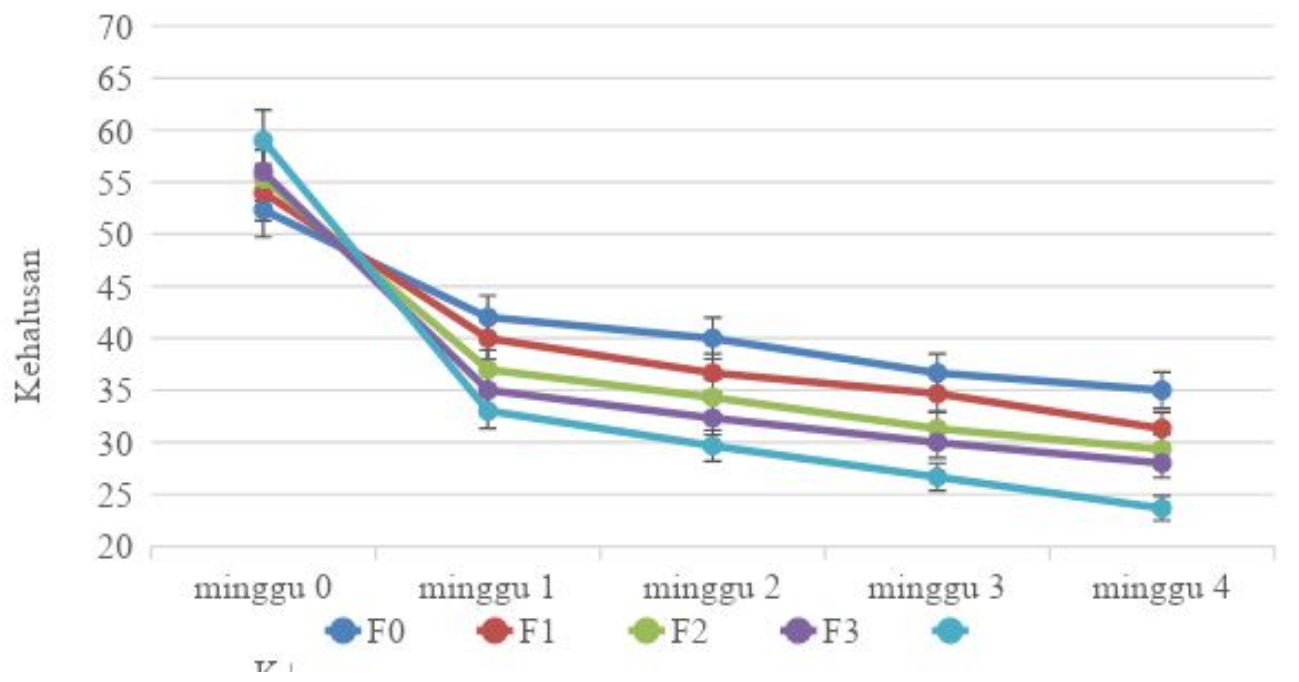

Gambar 1 Hasil pengukuran kehalusan kulit pada sukarelawan selama 5 minggu

Terjadi penurunan angka dalam pengukuran evenness/ kehalusan yang menunjukkan kondisi kulit yang semakin halus. Semakin tinggi angka yang ditunjukkan pada alat, menunjukkan kondisi kulit yang semakin kasar $^{11}$. Perbaikan atau persentase perubahan kehalusan kulit pada kulit sukarelawan dapat dilihat pada Gambar 2. 


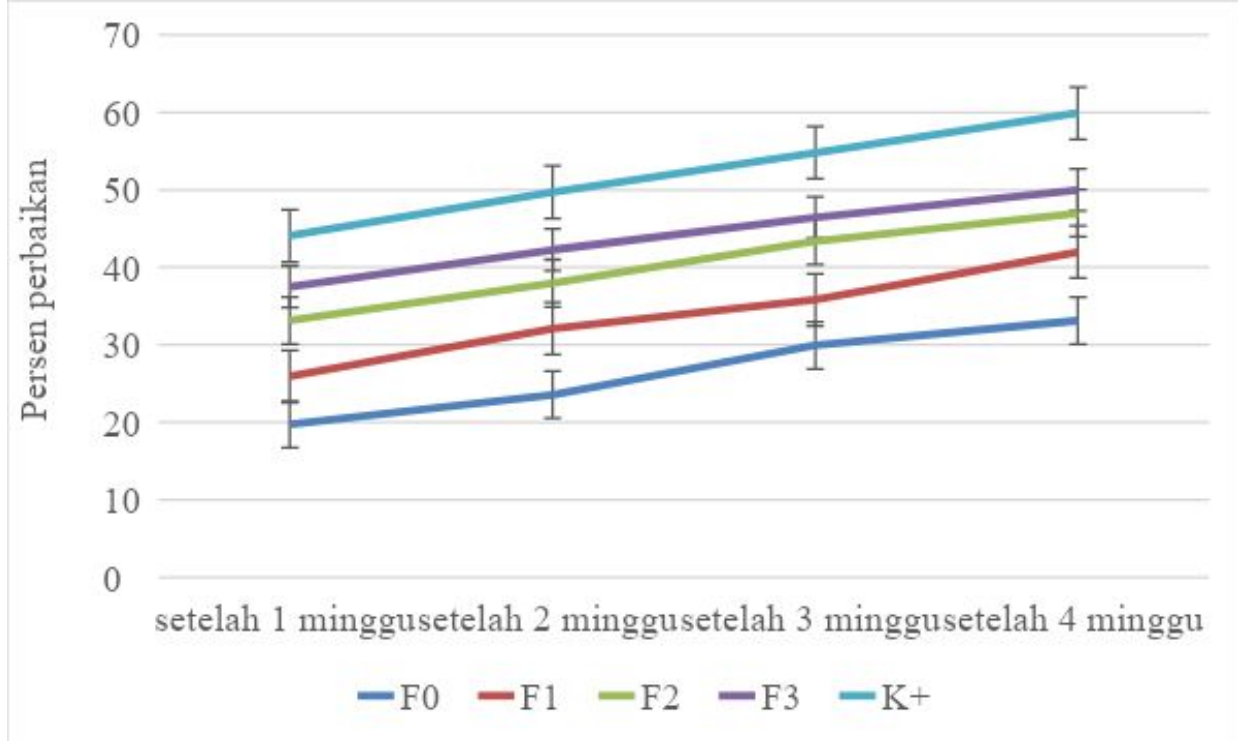

Gambar 2 Persentase perbaikan kehalusan kulit sukarelawan

Hasil pengukuran kadar air (moisture) pada kulit sukarelawan menunjukkan adanya peningkatan selama penggunaan sediaan dalam kurun waktu 4 minggu. Grafik kadar air pada sukarelawan dapat dilihat pada Gambar 3.

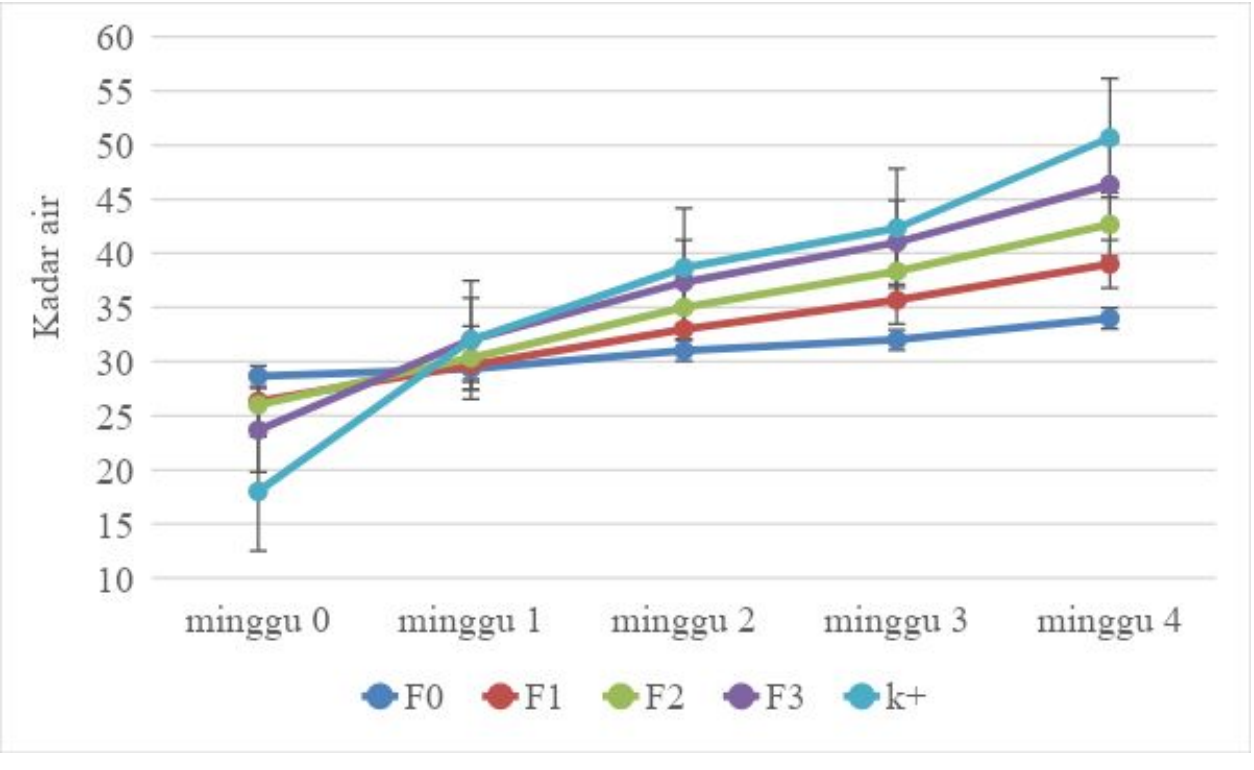

Gambar 3 Hasil pengukuran kadar air kulit sukarelawan

Grafik hasil persentase pemulihan kadar air pada kulit sukarelawan dapat dilihat pada Gambar 4. 


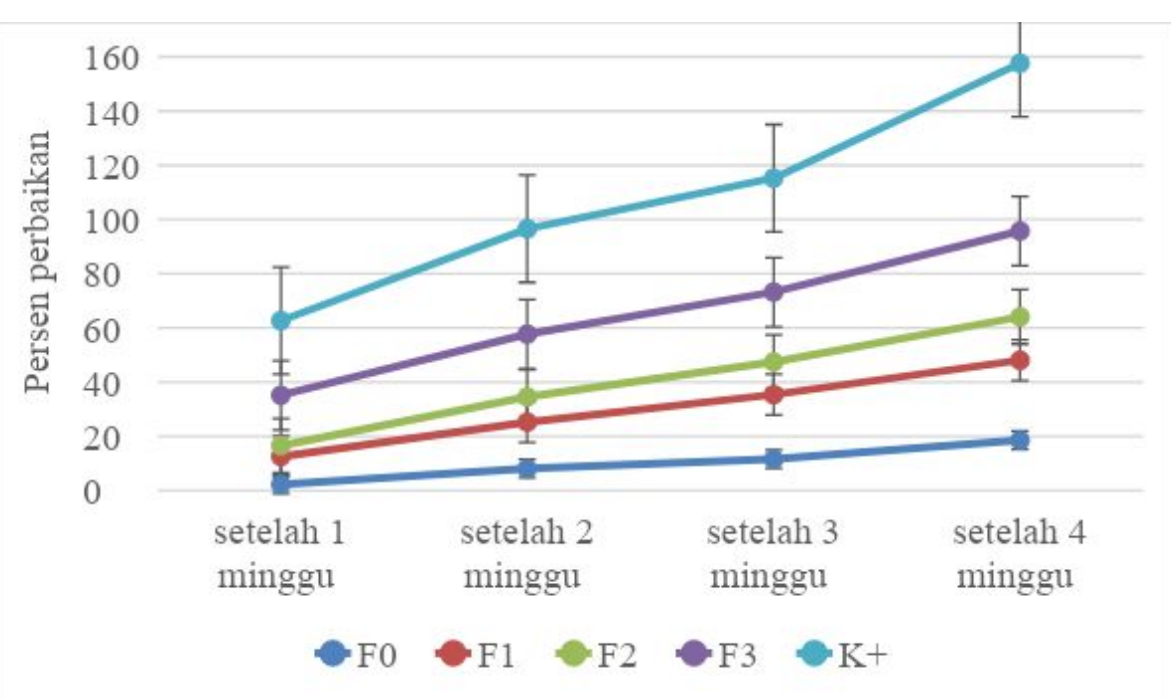

Gambar 4 Persentase perbaikan kadar air pada kulit sukarelawan

\section{Pembahasan}

Sediaan yang diperoleh berupa body scrub berbentuk krim, untuk F0 atau blanko, sediaan berwarna putih, untuk F1 hingga F3 sediaan berwarna kuning muda hingga kuning tua. Semua sediaan mempunyai bau khas aroma labu dan vanilla sebagai odoris yang ditambahkan pada sediaan. Semua sediaan body scrub homogen, mempunyai warna yang merata dan tidak terdapat gumpalan.

Homogenitas berpengaruh terhadap efektivitas terapi karena berhubungan dengan kadar obat yang sama pada setiap pemakaian, jika sediaan homogen maka kadar zat aktif pada setiap pemakaian diasumsikan akan sama, setiap bagian zat aktif akan harus memiliki kesempatan yang sama untuk menempati tempat terapi, sebaiknya setiap bagian tempat terapi memiliki kesempatan yang sama untuk dapat kontak dengan zat aktif, kondisi ini dapat tercapai bila sediaan homogen ${ }^{17-18}$.

Hasil pengamatan secara visual menunjukkan bahwa sediaan blanko dan ketiga body scrub dengan sari labu kuning pada penyimpanan suhu rendah $4^{\circ} \mathrm{C}$ dan suhu tinggi $40^{\circ}$ C selama enam siklus tidak mengalami perubahan warna, bau, dan konsistensi. Hal ini dapat menunjukkan kestabilan pada sediaan krim karena sesudah cycling test tidak terdapat perubahan seperti saat sebelum dilakukan pengujian cycling test ${ }^{16}$.

Penurunan $\mathrm{pH}$ juga terjadi dengan bertambahnya waktu penyimpanan, namun $\mathrm{pH}$ yang diperoleh masih berada dalam rentang persyaratan $\mathrm{pH}$ kulit yaitu 4,5-6,5. Jika krim memiliki $\mathrm{pH}$ yang terlalu asam dapat menyebabkan iritasi kulit karena semakin alkalis atau semakin asam dapat menyebabkan kulit menjadi kering, sedangkan $\mathrm{pH}$ terlalu basa dapat menyebabkan kulit menjadi bersisik, karena itu hendaknya $\mathrm{pH}$ sediaan kosmetik diusahakan sama atau sedekat mungkin dengan $\mathrm{pH}$ fisiologis kulit, yaitu antara 4,5-6,5. Kosmetik demikian disebut dengan $\mathrm{pH}$-balance. Selain itu perubahan $\mathrm{pH}$ juga disebabkan oleh faktor lingkungan seperti suhu, penyimpanan yang kurang baik, dan terjadi oksidasi ${ }^{19}$. 
Berdasarkan hasil analisa kondisi kulit dengan menggunakan skin analyzer, kehalusan kulit pada sukarelawan mengalami penurunan yaitu dari kategori kasar menjadi kulit halus untuk Formula F2, F3, dan kontrol positif. Sedangkan untuk F0 dan F1 kondisi kulit masih dalam keadaan kulit normal, namun hasil ini juga menunjukkan perbaikan yang baik karena mengalami penurunan tingkat kekasaran. Kadar kehalusan kulit yang berada di atas 52 adalah berada dalam kategori kasar, 32-51 menunjukkan kulit yang normal/sedang dan 0-31 menunjukkan kondisi kulit yang halus ${ }^{14}$. Pada pengukuran kadar air kulit, setelah perawatan selama 4 minggu, didapatkan peningkatan kadar air yang signifikan. Kondisi awal sukarelawan berada dalam kondisi kulit dehidrasi, namun setelah 4 minggu, kadar air sukarelawan meningkat hingga kategori normal. Kadar air kulit dehidrasi adalah dalam rentang 0-29, kulit normal mempunyai kadar air 30-51 dan jika diatas 51 maka kulit tergolong dalam kondisi terhidrasi ${ }^{14}$.

\section{Kesimpulan}

Sari buah labu kuning (Cucurbita moschata) dapat diformulasikan dalam bentuk sediaan krim body scrub yang stabil dimana tidak terjadi perubahan bau, warna dan konsistensi setelah dilakukan pengujian stabilitas. Formula yang memberikan efektivitas terbaik ialah formula body scrub dengan konsentrasi $20 \%$ sari labu kuning.

\section{Ucapan terima kasih}

Ucapan terima kasih disampaikan kepada Deputi Bidang Penguat Riset dan Pengembangan, Kementerian Riset dan Teknologi / Badan Riset dan Inovasi Nasional dan Lembaga Layanan Pendidikan Tinggi Wilayah I Sumatera Utara, Kementerian Pendidikan dan Kebudayaan dengan No kontrak 197/LL1/PG/2021 atas pendanaan yang diberikan sehingga penelitian ini dapat terlaksana dengan baik.

\section{Daftar Pustaka}

1. Maniek S. Pendayagunaan Buah Buah Labu Segar (Cucurbita Sp) Menjadi Intermediatte Product (Tepung Labu) Sebagai Upaya Menuju Pertumbuhaan Inklusi Berkelanjutan di wilayah Kabupaten Semarang. Lemb. Penelitian Dan Pengabdian Masyarakat. Semarang: Universitas Katolik Soegijaprinata; 2012.

2. Lasmida A. Aktivitas Antioksidan Dan Stabilitas Gel Anti-Aging Yang Mengandung Ekstrak Air Kentang Kuning (Solanum Tuberosum L.). Artik. IIm. Pada Program Ekstensi Fak. Farm. Univ. Indonesia: Jakarta; 2012.

3. Dkrigumulung. Analisis Beta Karoten Dari Ekstrak Jonjot Buah Labu Kuning (cucurbita moschata). Fullerene Journal of Chemistry. 2017; 2(2): 69-71.

4. Adini Aprilliana. Manfaat Labu Kuning Untuk Perawatan Kecantikan Kulit Yang Perlu Diketahui Para Wanita. Jakarta: Beauty J; 2017.

5. Iskandar B, Sidabutar SE, Leny. Formulasi dan Evaluasi Lotion Ekstrak Alpukat (Persea americana) sebagai Pelembab Kulit. Jurnal Islamic Pharmacy. 2021; 6(1): 14-21.

6. Leny, Fitri K, Marantina R, Ginting PA, Syamsul D, Hafiz I. The Moisturizing Sheet Mask Formulation of Black Soybean (Glycine soja) Ethanolic Extract. International Journal of Advanced Science and Technology. 2020; 29(4): 9045-9051. 
7. Safitri. Formulasi Sediaan Krim Pelembab Yang Mengandung Buah Labu Kuning (cucurbita moschata) (skripsi). Universitas Sumatera Utara; 2011.

8. Brotodjojo L. Semua Serba Labu Kuning. Jakarta: Gramedia Pustaka Utama; 2010.

9. Wasitaadmaja SM. Penuntun IImu Kosmetik Medik. Jakarta: UI-Press; 1997.

10. Novitasari NK. Uji Angka Lempeng Total Dan Identifikasi Staphlococcus Aureus Pada Lulur Tradisional. Karya Tulis IImiah. Jurnal Analisis Kesehatan. Politeknik Kemenkes Denpasar; 2018.

11. Leny, Karsono, Harahap U. Comparison of Vitamin C (Magnesium Ascorbyl Phosphate) Formulation in Nanoemulsion Spray and Cream as Anti-aging. International Journal of PharmTech Research. 2016; 9(9): 399-407.

12. Yumas M, Ramlah S, Mamang. Formulasi Lulur Krim dari Bubuk Kakao Non Fermentasi dan Efek Terhadap Kulit. Biopropal Industri. 2015;6(2):63-72.

13. Ditjen POM. Formularium Kosmetika Indonesia. Jakarta: Departemen Kesehatan Republik Indonesi; 2020.

14. Dewi RK. Optimasi Formulasi Mikroemulsi Sediaan Hormon Testosteron Undekanoat. Jakarta: Universitas Islam Negeri Syarif Hidayatullah; 2010.

15. Leny, Ginting EE, Hafiz I. Formulation and Evaluation of Candlenut (Aleurites moluccana L.) Oil in Gel Preparation, Asian Journal of Pharmaceutical Research and Development. 2020;8(5): 41-43.

16. Iskandar B, Karsono, Silalahi J. Preparation of Spray Nanoemulsion and Cream Containing Vitamin E as Anti-aging Product Tested in Vitro and in Vivo Method. International Journal PharmaTech Research. 2016;9(6): 307-308.

17. Iskandar B, Sidabutar SE, Leny. Formulasi dan Evaluasi Lotion Ekstrak Alpukat (Persea americana) sebagai Pelembab Kulit. Jurnal Islamic Pharmacy. 2021; 6(2): 36-45.

18. Iskandar B, Ernilawati M, Agustini TT, Firmansyah F, Frimayanti N. Formulasi blush on stick dengan zat pewarna alami ekstrak kering buah naga merah (Hylocereus polyrhizus L.). Cendekia journal of pharmacy. 2021;5(1): 70-80.

19. Swastika NSP, Mufrod A, Purwanto. 2013. Antioxidant Activity Of Cream Dosage Form Of Tomato Extract (Solanum lycopersicum L.) Aktivitas Antioksidan Krim Ekstrak Sari Tomat (Solanum lycopersicum L.). Tradititional Medicine Journal. 2013;18(3): 132-140.

20. Marta LZ, Agustinus R, Rizaldy T. Proses Menua, Stres Oksidatif Dan Peran Anti Oksidan. Yogyakarta: Artik. Fak. Kedokteran Universitas Duta Kristen Wacana; 2016.

21. Benson, Heather AE, Roberts, Micahel S, Leite-Silva, Vania, et al. Cosmetic formulation: Principles and Practice. France: CRC Press Taylor and francis Group; 2019. 